\title{
Analysis of Valence XPS of Hydrocarbon Polymers Modified by He-lon Bombardment
}

\author{
Seiji KoIzumi, Aiko NAKaO, ${ }^{*}$ Kazunaka Endo,${ }^{\dagger}$ Jun MAKI, ${ }^{* *}$ and Masaya IWAKI* \\ Department of Chemistry, Kanazawa University, Kakuma, Kanazawa 920-1192, Japan \\ *Institute of Physical and Chemical Research (RIKEN), Wako, Saitama 351-0198, Japan \\ ${ }^{* *} R \& D$ Applying Advanced Computational Science and Technology, Japan Science and Technology \\ Corporation, 4-1-3Honcho, Kawaguchi 332-0012, Japan
}

(Received May 1, 2001; Accepted June 15, 2001)

\begin{abstract}
Surface analysis of hydrocarbon polymers (polyethylene (PE), polypropylene (PP), polystyrene (PS)) by He-ion bombardment was performed from the theoretical and experimental valence X-Ray photoelectron spectra (XPS). The polymers were He-ion bombarded at an energy of $150 \mathrm{keV}$ with fluences between $1 \times 10^{12}$ and $1 \times 10^{15}$ ions $\mathrm{cm}^{-2}$. The bombardment destroys the chemical bonds of the polymer surface and activates carbon atoms near the surfaces. They may produce radicals and recombine with oxygen in the residual gas and/or atmospheric oxygen. We consider that experimental results for valence XPS of the polymers due to the bombardment are simulated by deMon density-functional theory (DFT) calculations using the model trimers, or dimer of neutral, radical, cationized, and oxidized compounds.

KEY WORDS Valence X-Ray Photoelectron Spectra (Valence XPS) / He-Ion Beam / Polymers (polyethylene, polypropylene, polystyrene Polymers (PE, PP, PS)) / Density-Functional Theory Calculation (DFT Calculation) /
\end{abstract}

Polymers are now used in widely many prototype applications such as material science in plastic moldings, sheets, fibers, and films, and in composites with inorganic materials, in protective coatings, sealants, and adhesives. In such applications, two groups of workers ${ }^{1,2}$ showed that ion bombardment is a useful method for modification of surface properties, such as wear resistance, corrosion resistance and bio-compatibility for polymers. Iwaki and co-workers ${ }^{3-7}$ have demonstrated that ion implantation or bombardment is applied to the surface modification of polymers to improve blood and tissue compatibility. As a fundamental investigation, it is very important to provide information on the surface and chemical bonding properties of such polymers. Nakao et al. ${ }^{8}$ investigated the chemical bonding states of carbon surface structure near the top surface of $\mathrm{Ne}$ ion-bombarded polystyrene and oxygen plasma-treated polystyrene by means of X-Ray photoelectron spectroscopy and surface-enhanced Raman spectroscopy to examine the cause of cell adhesion control on polymers. Recently, they ${ }^{9}$ have analyzed the relationship between surface chemical bonding states and He-ion bombarded effects of polyethylene and polypropylene with X-Ray photoelectron spectroscopy measurements. We think most of the interesting chemistry and physics of such ion-bombarded polymers are associated with the detail of the electronic structure at the valence band from theoretical and experimental viewpoints.

In recent studies using deMon density-functional the-

${ }^{\dagger}$ To whom correspondence should be addressed. ory (DFT) program ${ }^{10}$ which uses the idea of transitionstate, ${ }^{11}$ Endo and co-workers ${ }^{12-18}$ performed excellent assignments of XPS of seventy polymers by the DFT calculations using model oligomers, because they used the energy shift $\boldsymbol{W D}$ (work function $(\boldsymbol{W})$ and other energies (delta, $\boldsymbol{D}))^{12-18}$ to account for solid-state effects. The simulation of the valence spectra was performed on the model molecules using standard convolution by each Gaussian line shape and using the Gelius intensity model ${ }^{19}$ for molecular photo-ionization cross-sections. The line width of each peak of ionization energy $l_{k}$ was taken to be $0.10 I_{\mathrm{k}}$ (proportional to the ionization energy) as stated in previous works. ${ }^{12-14}$

In the present work, we perform surface analysis of hydrocarbon polymers (polyethylene (PE), polypropylene (PP), polystyrene (PS)) by He-ion bombardment from the theoretical and experimental valence X-Ray photoelectron spectra (XPS). In the case of He ionbombardment, He ions are light elements, compared with carbon, which is the main component of the polymers, and it would be expected that energy loss of injected He-ions to polymers is due only to inelastic collision. The bombardment destroys the chemical bonds of the polymer surface and activates carbon atoms near the surfaces. Thus, they may produce radicals and recombine with oxygen in the residual gas and/or atmospheric oxygen. We consider that experimental results for valence XPS of the polymers due to the bombardment are simulated by DFT calculations using the model trimers and dimer of neutral, radical, cationized, and oxidized 
compounds for (PE, PP) and PS, respectively.

\section{PRACTICAL DETAILS OF CALCULATION}

For the comparison between calculations for a single molecule of the (trimer and dimer) models and experiments on a solid polymer, we must shift each computed vertical ionization potentials (VIPs), $l_{\mathrm{k}}^{\prime}$ by a quantity $W D$ as $I_{\mathrm{k}}(\mathrm{EF})=I_{\mathrm{k}}^{\prime}-W D$, to convert to ionization energy $I_{\mathrm{k}}(\mathrm{EF})$ relative to the Fermi level. This quantity $W D$ denotes the sum of the work function of the sample and other energy effects, as stated in our previous studies. ${ }^{12-14}$

For ionization of an electron from molecular orbital (MO) $\phi_{\mathrm{k}}$, for example, we can apply the Janak theorem. ${ }^{20}$ For the VIPs of the valence regions, we use the so-called diffuse ionization (DI) model which Asbrink et al. ${ }^{21}$ proposed in the HAM/3 method. In the restricted DI model, half of an electron is removed evenly from the valence MOs and the negative of the resulting orbital energies correspond to calculated VIPs. This allows us to obtain all the valence VIPs in a single calculation.

In the deMon program, ${ }^{10}$ we used the maximum numbers of primitive bases in all contractions combined, contractions, orbitals, and atoms as 3600, 900, 255 , and 45 , respectively. We, thus, considered the model trimer and dimer for (PE, PP) and PS, respectively.

We calculated model trimer molecules of neutral, radical, cationized, and oxidized compounds, [H$\left(\mathrm{CH}_{2}-\mathrm{CHR}\right)_{3}-\mathrm{H},\left\{\mathrm{H}-\left(\mathrm{C}^{*} \mathrm{HCHR}\right)-\left(\mathrm{CH}_{2} \mathrm{CHR}\right)_{2}-\mathrm{H}, \mathrm{H}-\right.$ $\left(\mathrm{CH}_{2} \mathrm{C}^{*} \mathrm{R}\right)-\left(\mathrm{CH}_{2} \mathrm{CHR}\right)_{2}-\mathrm{H}, \mathrm{H}-\left(\mathrm{CH}_{2} \mathrm{CHR}\right)-(\mathrm{C} * \mathrm{HCH}-$ $\mathrm{R})-\left(\mathrm{CH}_{2} \mathrm{CHR}\right)-\mathrm{H}, \mathrm{H}-\left(\mathrm{CH}_{2} \mathrm{CHR}\right)-\left(\mathrm{CH}_{2} \mathrm{C} * \mathrm{R}\right)-\left(\mathrm{CH}_{2} \mathrm{C}-\right.$ $\mathrm{HR})-\mathrm{H}, \mathrm{H}-\left(\mathrm{CH}_{2} \mathrm{CHR}\right)_{2}-\left(\mathrm{C}^{*} \mathrm{HCHR}\right)-\mathrm{H}, \mathrm{H}-\left(\mathrm{CH}_{2} \mathrm{CH}-\right.$ $\left.\mathrm{R})_{2}-\left(\mathrm{CH}_{2} \mathrm{C}^{*} \mathrm{R}\right)-\mathrm{H}\right\},\left\{\mathrm{H}-\left(\mathrm{C}^{+} \mathrm{HCHR}\right)-\left(\mathrm{CH}_{2} \mathrm{CHR}\right)_{2}-\mathrm{H}\right.$, $\mathrm{H}-\left(\mathrm{CH}_{2} \mathrm{C}^{+} \mathrm{R}\right)-\left(\mathrm{CH}_{2} \mathrm{CHR}\right)_{2}-\mathrm{H}, \mathrm{H}-\left(\mathrm{CH}_{2} \mathrm{CHR}\right)-\left(\mathrm{C}^{+} \mathrm{H}-\right.$ CHR $)-\left(\mathrm{CH}_{2} \mathrm{CHR}\right)-\mathrm{H}, \mathrm{H}-\left(\mathrm{CH}_{2} \mathrm{CHR}\right)-\left(\mathrm{CH}_{2} \mathrm{C}^{+} \mathrm{R}\right)-(\mathrm{C}-$ $\left.\mathrm{H}_{2} \mathrm{CHR}\right)-\mathrm{H}, \mathrm{H}-\left(\mathrm{CH}_{2} \mathrm{R}\right)_{2}-\left(\mathrm{C}^{+} \mathrm{HCHR}\right)-\mathrm{H}, \mathrm{H}-\left(\mathrm{CH}_{2} \mathrm{C}-\right.$ $\left.\mathrm{HR})_{2}-\left(\mathrm{CH}_{2}-\mathrm{C}^{+} \mathrm{R}\right)-\mathrm{H}\right\},\left\{\mathrm{H}-(\mathrm{CMCHR})-\left(\mathrm{CH}_{2} \mathrm{CHR}\right)_{2}-\right.$ $\mathrm{H}, \mathrm{H}-\left(\mathrm{CH}_{2} \mathrm{CM}\right)-\left(\mathrm{CH}_{2} \mathrm{CH}_{2}\right)_{2}-\mathrm{H}, \mathrm{H}-\left(\mathrm{CH}_{2} \mathrm{CHR}\right)-(\mathrm{C}-$ MCHR $)-\left(\mathrm{CH}_{2} \mathrm{CHR}\right)-\mathrm{H}, \mathrm{H}-\left(\mathrm{CH}_{2} \mathrm{CH}_{2}\right)-\left(\mathrm{CH}_{2} \mathrm{CM}\right)-$ $\left(\mathrm{CH}_{2} \mathrm{CH}_{2}\right)-\mathrm{H}, \mathrm{H}-\left(\mathrm{CH}_{2} \mathrm{CHR}\right)_{2}-(\mathrm{CMCHR})-\mathrm{H}, \mathrm{H}-(\mathrm{C}-$ $\left.\left.\mathrm{H}_{2} \mathrm{CH}_{2}\right)_{2}-\left(\mathrm{CH}_{2} \mathrm{CM}\right)-\mathrm{H}\right\}(\mathrm{M}=\mathrm{O})$, and $\{\mathrm{H}-(\mathrm{CHXC}-$ $\mathrm{HR})-\left(\mathrm{CH}_{2} \mathrm{CHR}\right)_{2}-\mathrm{H}, \mathrm{H}-\left(\mathrm{CH}_{2} \mathrm{CRX}\right)-\left(\mathrm{CH}_{2} \mathrm{CHR}\right)_{2}-\mathrm{H}$, $\mathrm{H}-\left(\mathrm{CH}_{2} \mathrm{CHR}\right)-(\mathrm{CHXCHR})-\left(\mathrm{CH}_{2} \mathrm{CHR}\right)-\mathrm{H}, \mathrm{H}-\left(\mathrm{CH}_{2}-\right.$ $\mathrm{CHR})-\left(\mathrm{CH}_{2} \mathrm{CRX}\right)-\left(\mathrm{CH}_{2} \mathrm{CHR}\right)-\mathrm{H}, \mathrm{H}-\left(\mathrm{CH}_{2} \mathrm{CHR}\right)_{2}-$ (CHXCHR)-H, $\mathrm{H}-\left(\mathrm{CH}_{2} \mathrm{CH}_{2}\right)_{2}-\left(\mathrm{CH}_{2} \mathrm{CRX}\right)-\mathrm{H}(\mathrm{X}=$ $\left.\left.\mathrm{OH}, \mathrm{OCH}_{3}, \mathrm{OOH}, \mathrm{OOCH}_{3}\right)\right]\left(\mathrm{R}=\mathrm{H}, \mathrm{CH}_{3}\right)$ for $(\mathrm{PE}$ and $\mathrm{PP})$, and the dimer models $\left[\mathrm{H}-\left(\mathrm{CH}_{2} \mathrm{CHC}_{6} \mathrm{H}_{5} \mathrm{C}-\right.\right.$ $\left.\mathrm{H}_{2} \mathrm{CHC}_{6} \mathrm{H}_{5}\right)-\mathrm{H},\left\{\mathrm{H}-\left(\mathrm{C}^{*} \mathrm{HCHC}_{6} \mathrm{H}_{5} \mathrm{CH}_{2} \mathrm{CHC}_{6} \mathrm{H}_{5}\right)-\right.$ $\mathrm{H}, \mathrm{H}-\left(\mathrm{CH}_{2} \mathrm{C}^{*} \mathrm{C}_{6} \mathrm{H}_{5}-\mathrm{CH}_{2} \mathrm{CHC}_{6} \mathrm{H}_{5}\right)-\mathrm{H}, \mathrm{H}-\left(\mathrm{CH}_{2} \mathrm{CH}-\right.$ $\left.\mathrm{C}_{6} \mathrm{H}_{5} \mathrm{C}^{*} \mathrm{HCHC}_{6} \mathrm{H}_{5}\right)-\mathrm{H}$, or $\mathrm{H}-\left(\mathrm{CH}_{2} \mathrm{CHC}_{6} \mathrm{H}_{5} \mathrm{CH}_{2} \mathrm{C}^{*}-\right.$
$\left.\left.\mathrm{C}_{6} \mathrm{H}_{5}\right)-\mathrm{H}\right\},\left\{\mathrm{H}-\left(\mathrm{C}^{+} \mathrm{HCHC}_{6} \mathrm{H}_{5} \mathrm{CH}_{2} \mathrm{CHC}_{6} \mathrm{H}_{5}\right)-\mathrm{H}, \mathrm{H}-\right.$ $\left(\mathrm{CH}_{2} \mathrm{C}^{+} \mathrm{C}_{6} \mathrm{H}_{5} \mathrm{CH}_{2} \mathrm{CHC}_{6} \mathrm{H}_{5}\right)-\mathrm{H}, \mathrm{H}-\left(\mathrm{CH}_{2} \mathrm{CHC}_{6} \mathrm{H}_{5} \mathrm{C}^{+}-\right.$ $\left.\mathrm{HCHC}_{6} \mathrm{H}_{5}\right)-\mathrm{H}$, or $\mathrm{H}-\left(\mathrm{CH}_{2} \mathrm{CHC}_{6} \mathrm{H}_{5} \mathrm{CH}_{2} \mathrm{C}^{+} \mathrm{C}_{6} \mathrm{H}_{5}\right)-$ $\mathrm{H}\},\left\{\mathrm{H}-\left(\mathrm{CRCHC}_{6} \mathrm{H}_{5} \mathrm{CH}_{2} \mathrm{CHC}_{6} \mathrm{H}_{5}\right)-\mathrm{H}\right.$, or $\mathrm{H}-\left(\mathrm{CH}_{2}-\right.$ $\left.\left.\mathrm{CHC}_{6} \mathrm{H}_{5} \mathrm{CR}-\mathrm{CHC}_{6} \mathrm{H}_{5}\right)-\mathrm{H}\right\}(\mathrm{R}=\mathrm{O})$, and $\{\mathrm{H}-(\mathrm{CHX}-$ $\left.\mathrm{CHC}_{6} \mathrm{H}_{5} \mathrm{CH}_{2} \mathrm{CHC}_{6} \mathrm{H}_{5}\right)-\mathrm{H}, \mathrm{H}-\left(\mathrm{CH}_{2} \mathrm{CXC}_{6} \mathrm{H}_{5} \mathrm{CH}_{2} \mathrm{CH}-\right.$ $\left.\mathrm{C}_{6} \mathrm{H}_{5}\right)-\mathrm{H}, \mathrm{H}-\left(\mathrm{CH}_{2} \mathrm{CHC}_{6} \mathrm{H}_{5} \mathrm{CHXCHC}_{6} \mathrm{H}_{5}\right)-\mathrm{H}$, or H$\left.\left.\left(\mathrm{CH}_{2} \mathrm{CHC}_{6} \mathrm{H}_{5} \mathrm{CH}_{2} \mathrm{CXC}_{6} \mathrm{H}_{5}\right)-\mathrm{H}\right\}\right]$ ( $\mathrm{X}=\mathrm{OH}, \mathrm{OCH}_{3}$, $\left.\mathrm{OOH}, \mathrm{OOCH}_{3}\right)$ ] for PS, respectively by deMon DFT program. ${ }^{10}$ For the geometry of the molecules, we used the optimized cartesian coordinates from the semiempirical AM1 (version 6.0) method. ${ }^{22}$

The deMon calculations were performed with the exchange-correlation potential labeled as B88/P86, made from Becke's 1988 exchange functiona ${ }^{3}$ and Perdew's 1986 correlation functional. ${ }^{24}$ In the program, we used a nonrandom grid and a polarized valence double-zeta (DZVP) basis of $\left(621 / 41 / 1^{*}\right)$ for $(\mathrm{C}, \mathrm{O})$, and (41) for $\mathrm{H}$ with auxiliary fitting functions labeled $(4,4 ; 4,4)$ for $(\mathrm{C}, \mathrm{O})$, and $(3,1 ; 3,1)$ for $\mathrm{H}$.

In order to simulate the valence XPS of polymers theoretically, we constructed from a superposition of peaks centered on the VIPs, $I_{\mathrm{k}}$. As was done in previous works, ${ }^{12-14}$ each peak was represented by a Gaussian curve. The intensity was estimated from the relative photo-ionization cross-section for $\mathrm{Mg}-K_{\alpha}$ radiation using the Gelius intensity model. ${ }^{19}$ For the relative atomic photo-ionization cross-section, we used the theoretical values from Yeh. ${ }^{25}$ In the case of the linewidth $(\mathrm{WH}(\mathrm{k}))$, we used $\mathrm{WH}(\mathrm{k})=0.10 I_{\mathrm{k}}$ for the models, as adopted in previous works. ${ }^{12-14}$

\section{EXPERIMENTAL}

We used commercially available PE (Hibron, SMK25: Mitsuitohatsu), PP (Tolephan: TORAY), and PS (Falcon 1008; Becton) substrates. He-ion bombardment was carried out at an energy of $150 \mathrm{keV}$ with fluences between $1 \times 10^{12}$ and $1 \times 10^{15}$ ions $\mathrm{cm}^{-2}$ at room temperature, using a RIKEN $200 \mathrm{kV}$ Low Current Implanter. The beam current density used was about $0.2 \mu \mathrm{A} \mathrm{cm}^{-2}$ to prevent the specimen from heating.

Experimental photoelectron spectra of the samples were obtained on a VG ESCALAB MKII spectrometer using $\mathrm{Mg}-K_{\alpha}(1253.6 \mathrm{eV})$ radiation. The applied power was operated at $15 \mathrm{kV}$, and $20 \mathrm{~mA}$. The base pressure of the analysis chamber was less than $\sim 10^{-7} \mathrm{~Pa}$. Standardization was achieved using the $\mathrm{Au} 4 \mathrm{f}_{7 / 2}(83.8 \mathrm{eV})$ transition. Smoothing, background removal, and peak fitting were carried out with a VG analysis software package, ECLIPS. 
A) $\mathrm{PE}$

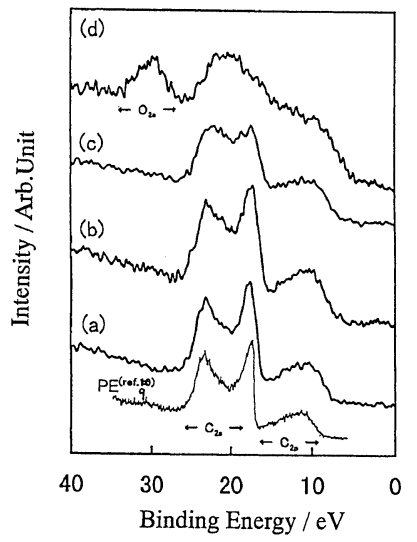

B) PP

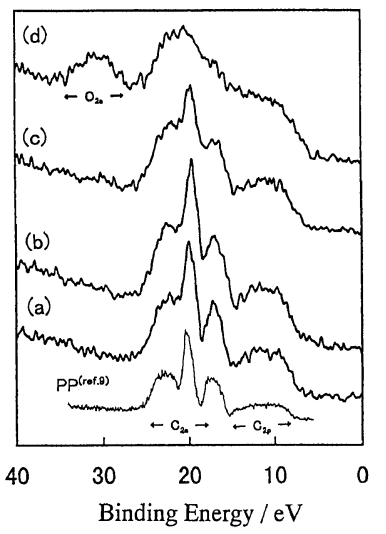

C) PS

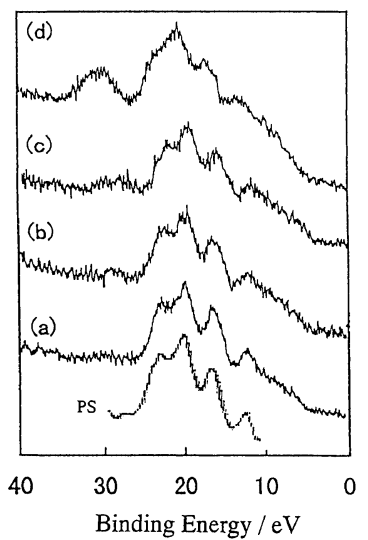

Figure 2. Experimental valence XPS of He-ion bombarded hydrocarbon polymers in the fluence range of $1 \times 10^{12}-1 \times 10^{15}\left((\mathrm{a}) 1 \times 10^{12}\right.$, (b) $1 \times 10^{13}$, (c) $1 \times 10^{14}$, (d) $1 \times 10^{15}$ ) ions $\mathrm{cm}^{-2}$ at an energy of $150 \mathrm{keV}$. A) PE, B) PP, C) PS.

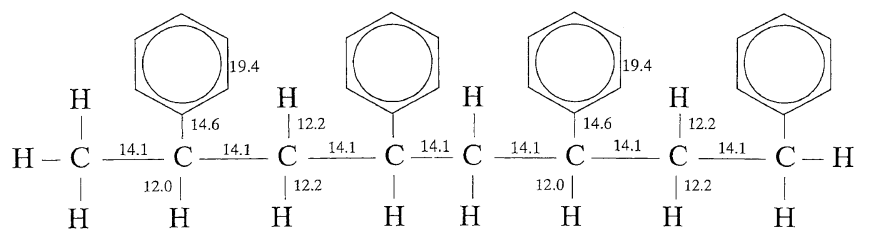

Figure 1. Two-center bond energies for the model tetramer of PS.

\section{RESULTS AND DISCUSSION}

\section{Experimental Spectra for He-Ion Bombarded Polymers}

With a $\mathrm{He}$ ion-bombardment the energy loss to the polymers is considered to be due to inelastic collision, since the He ion is a light element, compared with carbon, which is the main component of the polymers. We, then, think thermal effects may be more important. We will, thus, predict where the cleavage of the polymerbond occurs in a He-ion bombardment, although the decomposition process of surface damage due to the bombardment may be very complicated. When we consider the dissociation of the molecule species on the surface as the thermal effects, the cleavage of polymer-bonds can be estimated from the two-center bond energies of the models by MO calculations using AM1 method, as indicated in our previous works. ${ }^{26,27}$

We obtained the two-center bond energies of $\mathrm{C}-\mathrm{H}$ bonds for the model pentamer of PE and PP as 12.0$12.2 \mathrm{eV}$ less than $14.1 \mathrm{eV}$ for $\mathrm{C}-\mathrm{C}$ bonds of the main chain as shown in our previous work. ${ }^{27}$ In Figure 1, the two-center bond energies of $\mathrm{C}-\mathrm{H}$ bonds for the model tetramer of PS showed $12.0-12.2 \mathrm{eV}$ less than $14.1 \mathrm{eV}$ and $19.4 \mathrm{eV}$ for $\mathrm{C}-\mathrm{C}$ bonds of the main chain and phenyl rings, respectively. Then, the cleavage of the $\mathrm{C}-\mathrm{H}$ bonds in the main chain occurs first in the hydrocarbon polymers: After a He ion-bombardment the $\mathrm{C}-\mathrm{H}$ scission of the polymers occurs easily, although the recombination of $\mathrm{C}-\mathrm{H}$ bonds may produce. Experimentally, the bombardment destroys the chemical bonds of the polymer surface and activates carbon atoms near the surfaces. Thus, we think they produce radicals and recombine with oxygen in the residual gas and/or atmospheric oxygen.

In Figure $2 \mathrm{~A}$ )-C), we showed the valence XPS of He-ion bombarded PE, PP, and PS polymers, respectively in the fluence range of $1 \times 10^{12}-1 \times 10^{15}$ ions $\mathrm{cm}^{-2}$ at an energy of $150 \mathrm{keV}$. The valence spectra keep similar shapes with slightly broadening to the polymers in the fluence range of $1 \times 10^{12}-1 \times 10^{14}$ ions $\mathrm{cm}^{-2}$, while the drastic change is observed for $1 \times 10^{15}$ ions $\mathrm{cm}^{-2}$ He-ion bombarded polymers. In the former spectra with slightly broadening, we can consider that the carbon radical or cation produces on the main chain of the polymers due to the $\mathrm{C}-\mathrm{H}$ scission. For the latter spectra in the drastic change, we can find new broader peaks at around $30 \mathrm{eV}$ and much broader spectra in the range of $5-25 \mathrm{eV}$. The peak at around $30 \mathrm{eV}$ is assigned to the $\mathrm{O} 2 \mathrm{~s}$ atomic orbital photo-ionization cross-section. Then, the carbons of the polymer chains are considered to recombine with oxygen in the residual gas and/or atmospheric oxygen owing to the He-ion bombardment of $1 \times 10^{15}$ ions cm ${ }^{-2}$.

\section{Decomposition Mechanism for He-Ion Bombarded Polymers}

From the spectral changes of He-ion bombarded polymers in the fluence range of $1 \times 10^{12}-1 \times 10^{15}$ ions $\mathrm{cm}^{-2}$ at an energy of $150 \mathrm{keV}$, the surface decomposition mechanism of PE and PP polymers with He-ion bombardment fluences will be classified as three processes (We omitted similar decomposition processes of 
(I) in non-bombardment,

$$
\mathrm{H}-\left\{\mathrm{CH}_{2} \mathrm{CHR}\right\}_{n}-\mathrm{H}
$$$$
\left(\mathrm{R}=\mathrm{H}, \mathrm{CH}_{3}\right) \text {, }
$$

(II) in the fluence range of $1 \times 10^{12}-1 \times 10^{14}$ ions $\mathbf{~ c m}^{-2}$,

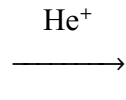

$$
\begin{aligned}
& {\left[(\mathrm{a}) \mathrm{H}-\left\{\left(\mathrm{C}^{*} \mathrm{HCHR}\right)-\left(\mathrm{CH}_{2} \mathrm{CHR}\right)_{2}\right\}_{m}-\mathrm{H},\right.} \\
& \text { (b) } \mathrm{H}-\left\{\left(\mathrm{CH}_{2} \mathrm{C} \text { R }\right)-\left(\mathrm{CH}_{2} \mathrm{CHR}\right)_{2}\right\}_{m}-\mathrm{H}, \\
& \text { (c) } \mathrm{H}-\left\{\left(\mathrm{CH}_{2} \mathrm{CHR}\right)-\left(\mathrm{C}^{*} \mathrm{HCHR}\right)-\left(\mathrm{CH}_{2} \mathrm{CHR}\right)\right\}_{m}-\mathrm{H}, \\
& \text { (d) } \mathrm{H}-\left\{\left(\mathrm{CH}_{2} \mathrm{CHR}\right)-\left(\mathrm{CH}_{2} \mathrm{C}^{*} \mathrm{R}\right)-\left(\mathrm{CH}_{2} \mathrm{CHR}\right)\right\}_{m}-\mathrm{H}, \\
& \text { (e) } \mathrm{H}-\left\{\left(\mathrm{CH}_{2} \mathrm{CHR}\right)_{2}-\left(\mathrm{C}^{*} \mathrm{HCHR}\right)\right\}_{m}-\mathrm{H}, \\
& \text { or } \left.\text { (f) } \mathrm{H}-\left\{\left(\mathrm{CH}_{2} \mathrm{CHR}\right)_{2}-\left(\mathrm{CH}_{2} \mathrm{C}^{*} \mathrm{R}\right)\right\}_{m}-\mathrm{H}\right]\left(\mathrm{R}=\mathrm{H}, \mathrm{CH}_{3}\right), \\
& \text { and }\left[(\mathrm{g}) \mathrm{H}-\left\{\left(\mathrm{C}^{+} \mathrm{HCHR}\right)-\left(\mathrm{CH}_{2} \mathrm{CHR}\right)_{2}\right\}_{m}-\mathrm{H},\right. \\
& \text { (h) } \mathrm{H}-\left\{\left(\mathrm{CH}_{2} \mathrm{C}^{+} \mathrm{R}\right)-\left(\mathrm{CH}_{2} \mathrm{CHR}\right)_{2}\right\}_{m}-\mathrm{H}, \\
& \text { (i) } \mathrm{H}-\left\{\left(\mathrm{CH}_{2} \mathrm{CHR}\right)-\left(\mathrm{C}^{+} \mathrm{HCHR}\right)-\left(\mathrm{CH}_{2} \mathrm{CHR}\right)\right\}_{m}-\mathrm{H}, \\
& \text { (j) } \mathrm{H}-\left\{\left(\mathrm{CH}_{2} \mathrm{CHR}\right)-\left(\mathrm{CH}_{2} \mathrm{C}^{+} \mathrm{R}\right)-\left(\mathrm{CH}_{2} \mathrm{CHR}\right)\right\}_{m}-\mathrm{H}, \\
& \text { (k) } \mathrm{H}-\left\{\left(\mathrm{CH}_{2} \mathrm{CHR}\right)_{2}-\left(\mathrm{C}^{+} \mathrm{HCHR}\right)\right\}_{m}-\mathrm{H}, \\
& \text { or } \left.\text { (l) } \mathrm{H}-\left\{\left(\mathrm{CH}_{2} \mathrm{CHR}\right)_{2}-\left(\mathrm{CH}_{2} \mathrm{C}^{+} \mathrm{R}\right)\right\}_{m}-\mathrm{H}\right]\left(\mathrm{R}=\mathrm{H}, \mathrm{CH}_{3}\right),
\end{aligned}
$$

(III) for $1 \times 10^{15}$ ions $\mathrm{cm}^{-2} \mathrm{He}$-ion bombardment,

$$
\begin{aligned}
& \mathbf{O}_{2} \\
& {\left[\left\{(\mathrm{~m}) \mathrm{H}-\left\{(\mathrm{CMCHR})-\left(\mathrm{CH}_{2} \mathrm{CHR}\right)_{2}\right\}_{m}-\mathrm{H}\right.\right. \text {, }} \\
& \text { (n) } \mathrm{H}-\left\{\left(\mathrm{CH}_{2} \mathrm{CM}\right)-\left(\mathrm{CH}_{2} \mathrm{CH}_{2}\right)_{2}\right\}_{m}-\mathrm{H} \text {, } \\
& \text { (o) } \mathrm{H}-\left\{\left(\mathrm{CH}_{2} \mathrm{CHR}\right)-(\mathrm{CMCHR})-\left(\mathrm{CH}_{2} \mathrm{CHR}\right)\right\}_{m}-\mathrm{H} \text {, } \\
& \text { (p) } \mathrm{H}-\left\{\left(\mathrm{CH}_{2} \mathrm{CH}_{2}\right)-\left(\mathrm{CH}_{2} \mathrm{CM}\right)-\left(\mathrm{CH}_{2} \mathrm{CH}_{2}\right)\right\}_{m}-\mathrm{H} \text {, } \\
& \text { (q) } \mathrm{H}-\left\{\left(\mathrm{CH}_{2} \mathrm{CHR}\right)_{2}-(\mathrm{CMCHR})_{m}-\mathrm{H}\right. \text {, } \\
& \text { or } \left.(\mathrm{r}) \mathrm{H}-\left\{\left(\mathrm{CH}_{2} \mathrm{CH}_{2}\right)_{2}-\left(\mathrm{CH}_{2} \mathrm{CM}\right)\right\}_{m}-\mathrm{H}\right\}(\mathrm{M}=\mathrm{O}) \text {, } \\
& \text { and }\left\{(\mathrm{s}) \mathrm{H}-(\mathrm{CHXCHR})-\left(\mathrm{CH}_{2} \mathrm{CHR}\right)_{2}\right\}_{m}-\mathrm{H} \text {, } \\
& \text { (t) } \mathrm{H}-\left\{-\left(\mathrm{CH}_{2} \mathrm{CRX}\right)-\left(\mathrm{CH}_{2} \mathrm{CHR}\right)_{2}\right\}_{m}-\mathrm{H} \text {, } \\
& \text { (u) } \mathrm{H}-\left\{\left(\mathrm{CH}_{2} \mathrm{CHR}\right)-(\mathrm{CHXCHR})-\left(\mathrm{CH}_{2} \mathrm{CHR}\right)\right\}_{m}-\mathrm{H} \text {, } \\
& \text { (v) } \mathrm{H}-\left\{\left(\mathrm{CH}_{2} \mathrm{CHR}\right)-\left(\mathrm{CH}_{2} \mathrm{CRX}\right)-\left(\mathrm{CH}_{2} \mathrm{CHR}\right)\right\}_{m}-\mathrm{H} \text {, } \\
& \text { (w) } \mathrm{H}-\left\{\left(\mathrm{CH}_{2} \mathrm{CHR}\right)_{2}-(\mathrm{CHXCHR})\right\}_{m}-\mathrm{H} \text {, } \\
& \text { (x) } \mathrm{H}-\left\{\left(\mathrm{CH}_{2} \mathrm{CH}_{2}\right)_{2}-\left(\mathrm{CH}_{2} \mathrm{CRX}\right)_{m}-\mathrm{H},\right\} \\
& \left.\left(\mathrm{X}=\mathrm{OH}, \mathrm{OCH}_{3}, \mathrm{OOH}, \mathrm{OOCH}_{3}\right)\right]\left(\mathrm{R}=\mathrm{H}, \mathrm{CH}_{3}\right) .
\end{aligned}
$$
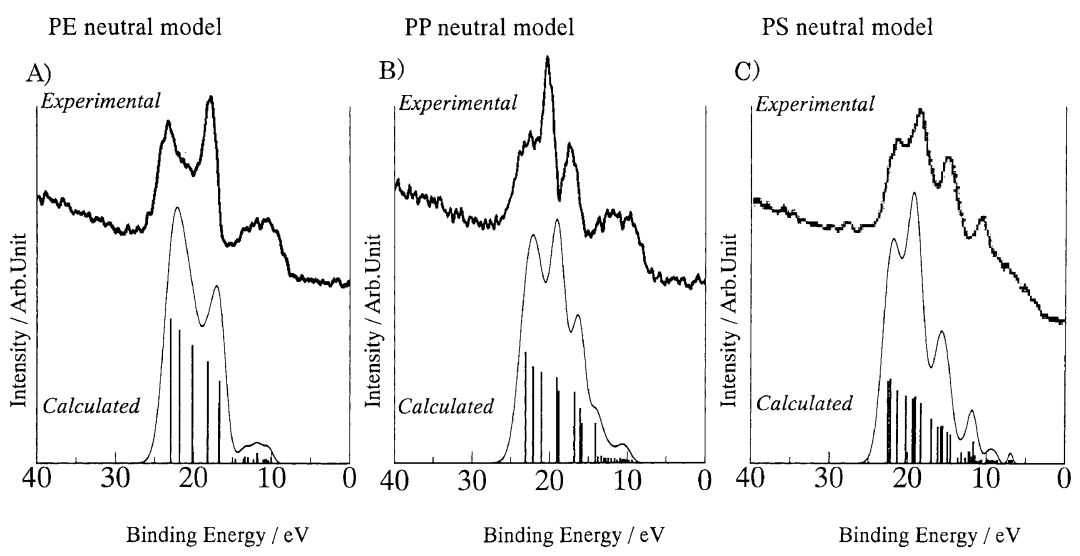

Figure 3. Simulated valence spectra of the model molecules of the polymers with the experimental ones at the initial state (in (I) nonbombardment). A) PE, B) PP, C) PS.

PS).

Let's consider the trimer models of (a)-(x) for the decomposition process of PE and PP with such dimer model of PS to analyze the valence electron spectra which constitute the unique fingerprint. In A)-C) of Figures 3-5, the simulated valence spectra of the neutral, radical, and cationized molecules showed good accordance with the experimental ones for PE, PP, and
PS at the initial state (in (I) non-bombardment), and in the He-ion bombardment fluence ranges of $1 \times 10^{12}$ and $1 \times 10^{14}$ ions $\mathrm{cm}^{-2}$ in (II), respectively. We didn't show the radical and cationized spectra in the cases of (b)(f) and (h)-(l), as the results were similar to those of Figures 4 and 5, respectively. Especially we considered the occurrence of the cationized carbon in the main chain to simulate the experimental broadening spectra, 

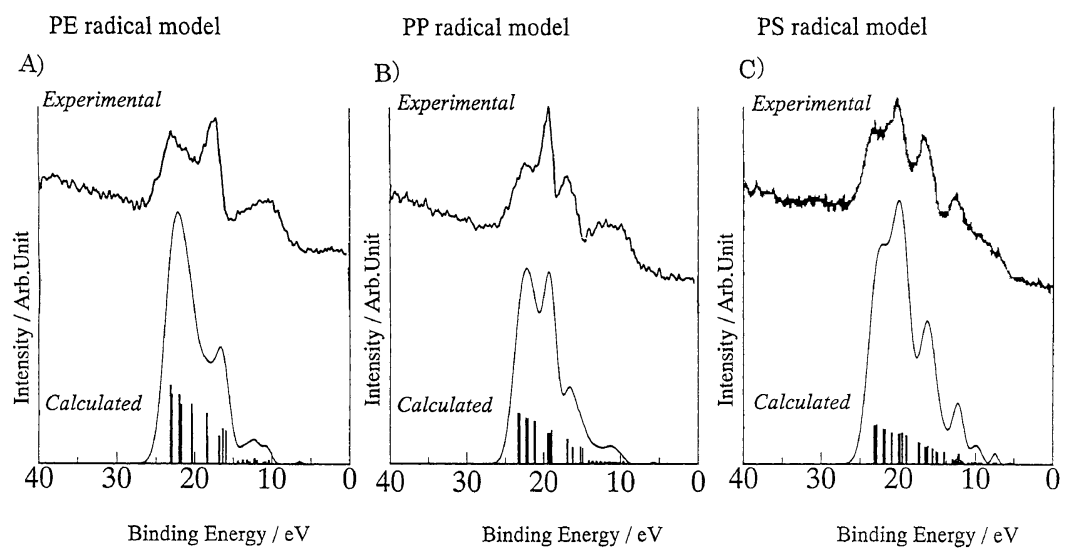

Figure 4. Simulated valence spectra of the radical molecules of the polymers with the experimental ones in the He-ion bombardment fluence range of $1 \times 10^{12}$ ions $\mathrm{cm}^{-2}$ in (II). A) PE, B) PP, C) PS.
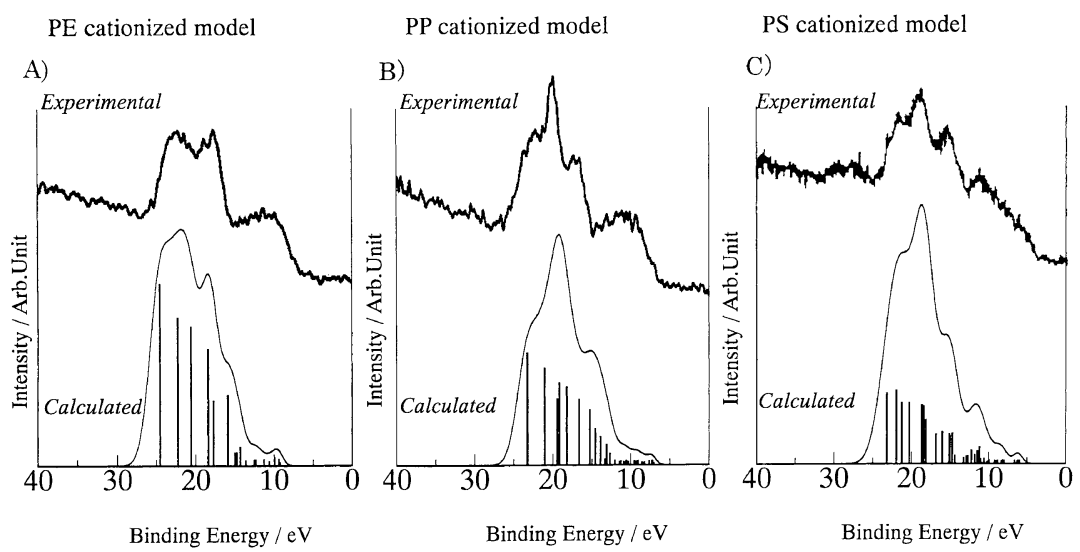

Figure 5. Simulated valence spectra of the cationized molecules of the polymers with the experimental ones in the He-ion bombardment fluence range of $1 \times 10^{14}$ ions $\mathrm{cm}^{-2}$ in (II). A) PE, B) PP, C) PS.

Table I. Observed peaks, calculated peaks, VIP, main AO photo-ionization cross-section, orbital nature, and the functional group for valence XPS of $\mathrm{H}-\left(\mathrm{CH}_{2} \mathrm{C}^{*} \mathrm{C}_{6} \mathrm{H}_{5} \mathrm{CH}_{2} \mathrm{CHC}_{6} \mathrm{H}_{5}\right)-\mathrm{H}$

\begin{tabular}{|c|c|c|c|c|}
\hline$\frac{\text { Observed peaks }}{\mathrm{eV}}$ & $\frac{\text { Calculated VIPs }}{\mathrm{eV}}$ & $\begin{array}{l}\text { Main AO photo-ioni- } \\
\text { zation cross-section }\end{array}$ & Orbital nature & $\begin{array}{l}\text { Functional } \\
\text { group }\end{array}$ \\
\hline $\begin{array}{c}20.0 \\
(18.0-22.0)^{\mathrm{a}}\end{array}$ & $\{23.61-22.36\}$ & $\mathrm{C} 2 \mathrm{~s}$ & $\mathrm{~s} \sigma(\mathrm{C} 2 \mathrm{~s}-\mathrm{C} 2 \mathrm{~s})-\mathrm{B}$ & $-\mathrm{C}-\mathrm{C}-$ \\
\hline $\begin{array}{c}17.0 \\
(16.0-18.0)^{\mathrm{a}}\end{array}$ & $\{21.45-18.37\}$ & $\mathrm{C} 2 \mathrm{~s}$ & $\mathrm{~s} \sigma(\mathrm{C} 2 \mathrm{~s}-\mathrm{C} 2 \mathrm{~s})-\mathrm{B}$ & $\begin{array}{c}-\mathrm{C}-\mathrm{C}- \\
-\mathrm{C}_{6} \mathrm{H}_{5}(\mathrm{Ph})\end{array}$ \\
\hline $\begin{array}{c}14.0 \\
(12.0-15.0)^{\mathrm{a}}\end{array}$ & $\{17.21-13.51\}$ & $\begin{array}{l}\mathrm{C} 2 \mathrm{~s} \\
\mathrm{C} 2 \mathrm{p}\end{array}$ & $\begin{array}{l}\mathrm{p} \sigma(\mathrm{C} 2 \mathrm{~s}-\mathrm{C} 2 \mathrm{p})-\mathrm{B} \\
\mathrm{p} \pi(\mathrm{C} 2 \mathrm{p}-\mathrm{C} 2 \mathrm{p})-\mathrm{B}\end{array}$ & $\begin{array}{c}-\mathrm{Ph}, \\
-\mathrm{C}-\mathrm{C}-,-\mathrm{Ph}\end{array}$ \\
\hline $\begin{array}{l}\text { Shoulder peak } \\
(5.0-11.0)^{\mathrm{a}}\end{array}$ & $\{13.19-5.98\}$ & $\mathrm{C} 2 \mathrm{p}$ & $\begin{array}{l}\mathrm{p} \pi(\mathrm{C} 2 \mathrm{p}-\mathrm{C} 2 \mathrm{p})-\mathrm{B} \\
\mathrm{p} \sigma(\mathrm{C} 2 \mathrm{p}-\mathrm{C} 2 \mathrm{p})-\mathrm{B}\end{array}$ & $\begin{array}{c}-\mathrm{Ph} \\
-\mathrm{C}-\mathrm{C}-\end{array}$ \\
\hline
\end{tabular}

${ }^{\mathrm{a}}$ Shows the peaks range. $W D$ (the gap between observed and calculated VIPs) $=3.0 \mathrm{eV}$.

although one can accept the occurrence of the carbon radical at the early step of the decomposition mechanism. We can thus conclude that, in the bombardment fluences, the carbon radical or cation produces on the main chain carbons of the PE, PP, and PS after the $\mathrm{C}-\mathrm{H}$ scission. In Table I, we showed the observed peaks, calculated peaks, VIP, main AO photoionization cross-section, orbital nature and the func- tional group for valence XPS of a radical molecule, $\mathrm{H}-$ $\left(\mathrm{CH}_{2} \mathrm{C}^{*} \mathrm{C}_{6} \mathrm{H}_{5}-\mathrm{CH}_{2} \mathrm{CHC}_{6} \mathrm{H}_{5}\right)-\mathrm{H}$ for PS polymer. The electronic state of the radical compound corresponds to that of the neutral PS.

In A)-C) of Figures 6-10, we showed the calculated valence spectra of each example $\{\mathrm{H}-(\mathrm{COCHR})-$ $\left(\mathrm{CH}_{2} \mathrm{CHR}\right)_{2}-\mathrm{H}\left(\mathrm{R}=\mathrm{H}, \mathrm{CH}_{3}\right), \mathrm{H}-\left(\mathrm{COCHC}_{6} \mathrm{H}_{5} \mathrm{CH}_{2}-\right.$ $\left.\left.\mathrm{CHC}_{6} \mathrm{H}_{5}\right)-\mathrm{H}\right\},\left\{\mathrm{H}-(\mathrm{CH}(\mathrm{OH}) \mathrm{CHR})-\left(\mathrm{CH}_{2} \mathrm{CHR}\right)_{2}-\mathrm{H}-\right.$ 

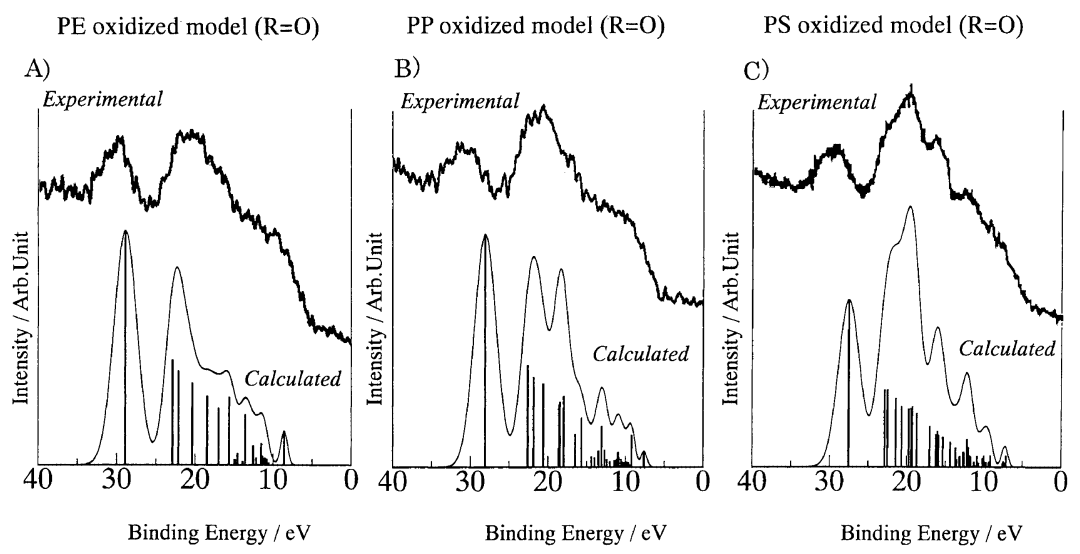

Figure 6. Simulated valence spectra of aldehyde molecule $H-\left(\mathrm{CORR}^{\prime} \mathrm{RR}{ }^{\prime} \mathrm{R}\right)-\mathrm{H}\left(\mathrm{R}, \mathrm{R}^{\prime}\right)=\left(\mathrm{CH}_{2}, \mathrm{CHX}\left(\mathrm{X}=\mathrm{H}, \mathrm{CH}_{3}, \mathrm{C}_{6} \mathrm{H}_{5}\right)\right)$ with the experimental ones in the He-ion bombardment of $1 \times 10^{15}$ ions $\mathrm{cm}^{-2}$ in (II). A) PE, B) PP, C) PS.
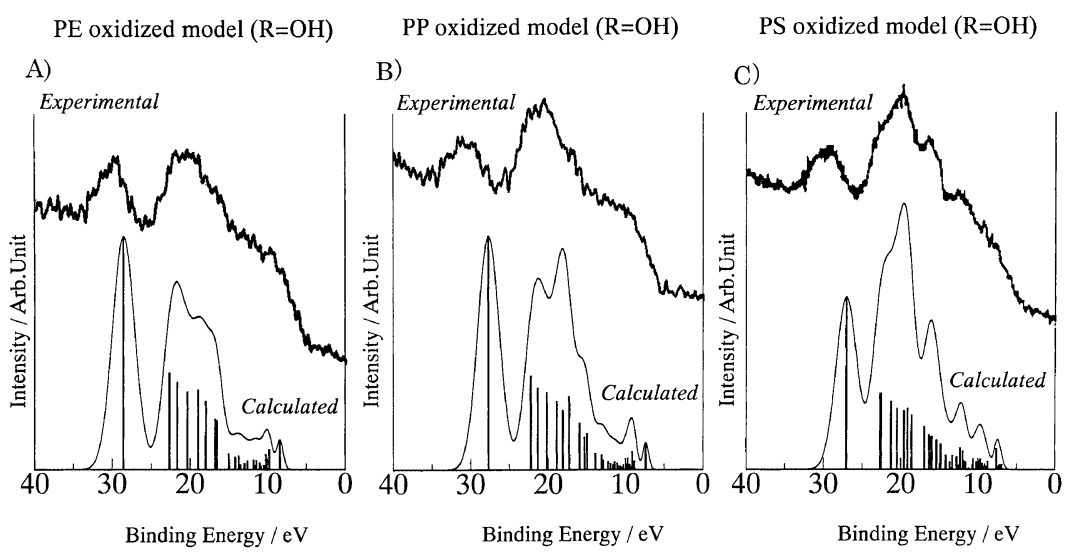

Figure 7. Simulated valence spectra of alcohol molecule $\mathrm{H}-\left(\mathrm{CHOHR}^{\prime} \mathrm{RR}^{\prime} \mathrm{RR} \mathrm{R}^{\prime}\right)-\mathrm{H}\left(\mathrm{R}, \mathrm{R}^{\prime}\right)=\left(\mathrm{CH}_{2}, \mathrm{CHX}\left(\mathrm{X}=\mathrm{H}, \mathrm{CH}_{3}, \mathrm{C}_{6} \mathrm{H}_{5}\right)\right)$ with the experimental ones in the He-ion bombardment of $1 \times 10^{15}$ ions $\mathrm{cm}^{-2}$ in (II). A) PE, B) PP, C) PS.
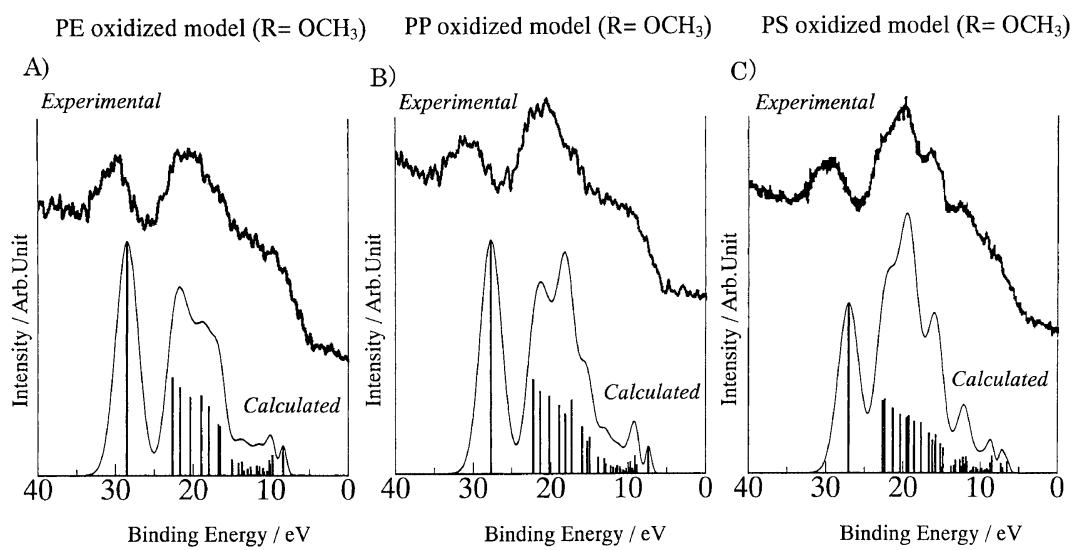

Figure 8. Simulated valence spectra of ether molecule $\mathrm{H}-\left(\mathrm{RC}\left(\mathrm{OCH}_{3}\right) \mathrm{RR}^{\prime} \mathrm{RR} \mathrm{R}^{\prime}\right)-\mathrm{H}\left(\mathrm{R}, \mathrm{R}^{\prime}\right)=\left(\mathrm{CH}_{2}, \mathrm{CHX}\left(\mathrm{X}=\mathrm{H}, \mathrm{CH}_{3}, \mathrm{C}_{6} \mathrm{H}_{5}\right)\right)$ with the experimental ones in the He-ion bombardment of $1 \times 10^{15}$ ions $\mathrm{cm}^{-2}$ in (II). A) PE, B) PP, C) PS.

$\left(\mathrm{R}=\mathrm{H}, \mathrm{CH}_{3}\right), \mathrm{H}-\left(\mathrm{CH}(\mathrm{OH}) \mathrm{CHC}_{6} \mathrm{H}_{5} \mathrm{CH}_{2} \mathrm{CHC}_{6} \mathrm{H}_{5}\right)-$ $\mathrm{H}\},\left\{\mathrm{H}-\left(\mathrm{CH}\left(\mathrm{OCH}_{3}\right) \mathrm{CHR}\right)-\left(\mathrm{CH}_{2} \mathrm{CHR}\right)_{2}-\mathrm{H}(\mathrm{R}=\mathrm{H}\right.$, $\left.\left.\mathrm{CH}_{3}\right), \mathrm{H}-\left(\mathrm{CH}\left(\mathrm{OCH}_{3}\right) \mathrm{CH}-\mathrm{C}_{6} \mathrm{H}_{5} \mathrm{CH}_{2} \mathrm{CHC}_{6} \mathrm{H}_{5}\right)-\mathrm{H}\right\}$, $\left\{\mathrm{H}-(\mathrm{CH}(\mathrm{OOH}) \mathrm{CHR})-\left(\mathrm{CH}_{2} \mathrm{CHR}\right)_{2}-\mathrm{H}\left(\mathrm{R}=\mathrm{H}, \mathrm{CH}_{3}\right)\right.$, $\left.\mathrm{H}-\left(\mathrm{CH}(\mathrm{OOH}) \mathrm{CHC}_{6} \mathrm{H}_{5} \mathrm{CH}_{2} \mathrm{CHC}_{6} \mathrm{H}_{5}\right)-\mathrm{H}\right\}$, and $\{\mathrm{H}-$ $\left(\mathrm{CH}\left(\mathrm{OOCH}_{3}\right) \mathrm{CHR}\right)-\left(\mathrm{CH}_{2} \mathrm{CHR}\right)_{2}-\mathrm{H} \quad\left(\mathrm{R}=\mathrm{H}, \quad \mathrm{CH}_{3}\right)$, $\left.\mathrm{H}-\left(\mathrm{CH}\left(\mathrm{OOCH}_{3}\right) \quad \mathrm{C}_{6} \mathrm{H}_{5} \mathrm{CH}_{2} \mathrm{CHC}_{6} \mathrm{H}_{5}\right)-\mathrm{H}\right\}$, respectively with the experimental valence spectra in the He-ion bombardment of $1 \times 10^{15}$ ions $\mathrm{cm}^{-2}$. We didn't show the oxidized spectra in the cases of (n)-(r) and $(\mathrm{t})-(\mathrm{x})$, as the results were similar to those of Figures 6-10, respectively. It can be seen in the figures that the spectra of aldehyde $H-\left(C O R R^{\prime} R R^{\prime} R\right)-H$, and $\left\{\right.$ alcohol $\mathrm{H}-\left(\mathrm{CH}(\mathrm{OH}) \mathrm{R}^{\prime} \mathrm{RR}^{\prime} \mathrm{RR}^{\prime}\right)-\mathrm{H}$, or ether $\left.\mathrm{H}-\left(\mathrm{RC}\left(\mathrm{OCH}_{3}\right) \mathrm{RR}^{\prime}-\mathrm{RR}^{\prime}\right)-\mathrm{H}\right\}\left(\mathrm{R}, \mathrm{R}^{\prime}\right)=\left(\mathrm{CH}_{2}, \mathrm{CHX}(\mathrm{X}\right.$ $\left.=\mathrm{H}, \mathrm{CH}_{3}, \mathrm{C}_{6} \mathrm{H}_{5}\right)$ ) are in good accordance with the observed ones in the He-ion bombardment. However, we concluded that the simulated spectra of 

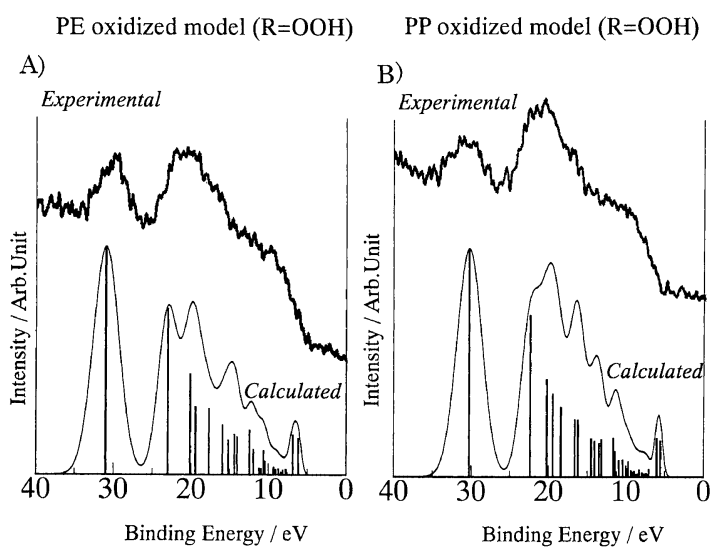

PS oxidized model $(\mathrm{R}=\mathrm{OOH})$

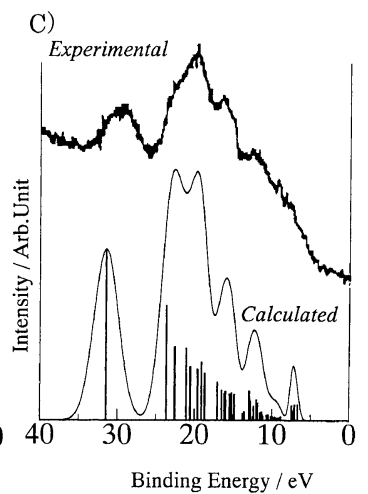

Figure 9. Simulated valence spectra of carboxylic acid molecule $\mathrm{H}-\left(\mathrm{RC}(\mathrm{OOH}) \mathrm{RR}^{\prime} \mathrm{RR}^{\prime}\right)-\mathrm{H}\left(\mathrm{R}, \mathrm{R}^{\prime}\right)=\left(\mathrm{CH}_{2}, \mathrm{CHX}\left(\mathrm{X}=\mathrm{H}, \mathrm{CH}_{3}, \mathrm{C}_{6} \mathrm{H}_{5}\right)\right)$ with the experimental ones in the He-ion bombardment of $1 \times 10^{15}$ ions $\mathrm{cm}^{-2}$ in (II). A) PE, B) PP, C) PS.

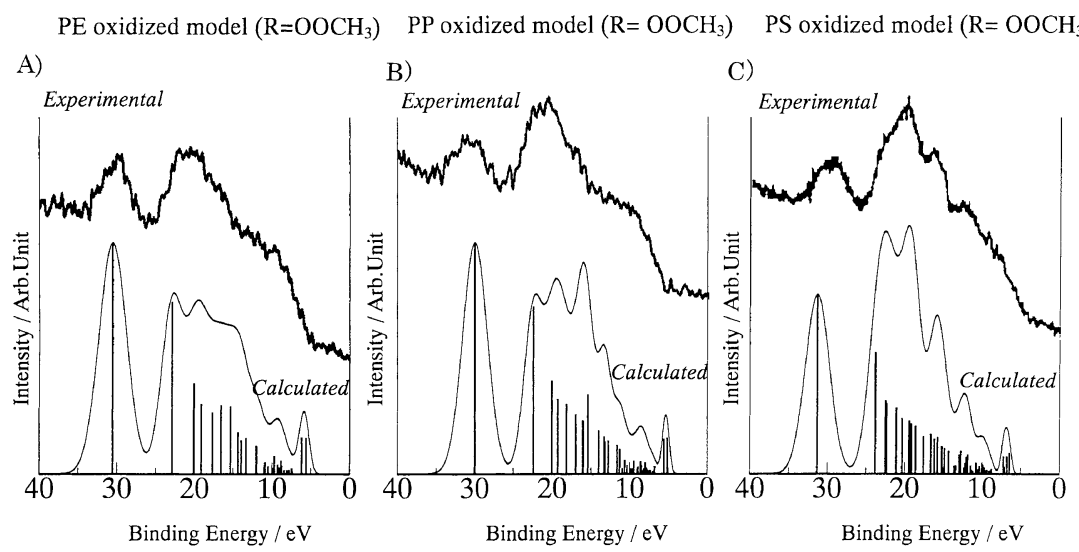

Figure 10. Simulated valence spectra of ester molecule $\mathrm{H}-\left(\mathrm{RC}\left(\mathrm{OOCH}_{3}\right) \mathrm{RR}^{\prime} \mathrm{RR}^{\prime}\right)-\mathrm{H}\left(\mathrm{R}, \mathrm{R}^{\prime}\right)=\left(\mathrm{CH}_{2}, \mathrm{CHX}\left(\mathrm{X}=\mathrm{H}, \mathrm{CH}_{3}, \mathrm{C}_{6} \mathrm{H}_{5}\right)\right)$ with the experimental ones in the He-ion bombardment of $1 \times 10^{15}$ ions $\mathrm{cm}^{-2}$ in (II). A) PE, B) PP, C) PS.

Table II. Observed peaks, calculated peaks, VIP, main $\mathrm{AO}$ photo-ionization cross-section, orbital nature, and the functional group for valence XPS of $\mathrm{H}-\left(\mathrm{CHOHCHC}_{6} \mathrm{H}_{5} \mathrm{CH}_{2} \mathrm{CHC}_{6} \mathrm{H}_{5}\right)-\mathrm{H}$

\begin{tabular}{|c|c|c|c|c|}
\hline$\frac{\text { Observed peaks }}{\mathrm{eV}}$ & $\frac{\text { Calculated VIPs }}{\mathrm{eV}}$ & $\begin{array}{l}\text { Main AO photoioni- } \\
\text { zation cross-section }\end{array}$ & Orbital nature & $\begin{array}{l}\text { Functional } \\
\text { group }\end{array}$ \\
\hline $\begin{array}{c}30 \\
(27.0-32.0)^{\mathrm{a}}\end{array}$ & 30.0 & $\mathrm{O} 2 \mathrm{~s}$ & $\mathrm{~s} \sigma(\mathrm{C} 2 \mathrm{~s}-\mathrm{O} 2 \mathrm{~s})-\mathrm{B}$ & $-\mathrm{C}-\mathrm{O}-$ \\
\hline $\begin{array}{c}20.0 \\
(18.0-24.0)^{\mathrm{a}}\end{array}$ & $25.6-24.2$ & $\mathrm{C} 2 \mathrm{~s}, \mathrm{O} 2 \mathrm{~s}$ & $\begin{array}{l}\mathrm{s} \sigma(\mathrm{C} 2 \mathrm{~s}-\mathrm{C} 2 \mathrm{~s})-\mathrm{B} \\
\mathrm{s} \sigma(\mathrm{C} 2 \mathrm{~s}-\mathrm{O} 2 \mathrm{~s})-\mathrm{B}\end{array}$ & $\begin{array}{c}-\mathrm{C}-\mathrm{C}=,-\mathrm{Ph} \\
-\mathrm{C}-\mathrm{O}-\end{array}$ \\
\hline $\begin{array}{c}17.0 \\
(16.0-18.0)^{\mathrm{a}}\end{array}$ & $23.5-21.6$ & $\mathrm{C} 2 \mathrm{~s}$ & $\begin{array}{l}\mathrm{s} \sigma(\mathrm{C} 2 \mathrm{~s}-\mathrm{C} 2 \mathrm{~s})-\mathrm{B} \\
\mathrm{p} \sigma(\mathrm{C} 2 \mathrm{~s}-\mathrm{C} 2 \mathrm{p})-\mathrm{B}\end{array}$ & $\begin{array}{c}-\mathrm{C}-\mathrm{C}-,-\mathrm{Ph} \\
-\mathrm{C}-\mathrm{C}=\end{array}$ \\
\hline $\begin{array}{c}14.0 \\
(12.0-15.0)^{\mathrm{a}}\end{array}$ & $19.9-17.1$ & $\mathrm{C} 2 \mathrm{~s}$ & $\mathrm{p} \sigma(\mathrm{C} 2 \mathrm{~s}-\mathrm{C} 2 \mathrm{p})-\mathrm{B}$ & $\begin{array}{c}-\mathrm{C}-\mathrm{C}-,-\mathrm{Ph} \\
-\mathrm{C}-\mathrm{C}=\end{array}$ \\
\hline \multirow[t]{4}{*}{$\begin{array}{l}\text { Shoulder peak } \\
(5.0-11.0)^{\mathrm{a}}\end{array}$} & $16.6-14.1$ & $\begin{array}{l}\mathrm{O} 2 \mathrm{p} \\
\mathrm{C} 2 \mathrm{p}\end{array}$ & $\begin{array}{l}\mathrm{p} \sigma(\mathrm{C} 2 \mathrm{~s}-\mathrm{O} 2 \mathrm{p})-\mathrm{B} \\
\mathrm{p} \sigma(\mathrm{C} 2 \mathrm{p}-\mathrm{C} 2 \mathrm{p})-\mathrm{B} \\
\mathrm{p} \pi(\mathrm{C} 2 \mathrm{p}-\mathrm{C} 2 \mathrm{p})-\mathrm{B}\end{array}$ & $\begin{array}{c}-\mathrm{C}-\mathrm{O} \\
-\mathrm{C}-\mathrm{C}-,-\mathrm{C}-\mathrm{C}= \\
-\mathrm{Ph}\end{array}$ \\
\hline & & $\mathrm{O} 2 \mathrm{p}$ & $\mathrm{p} \sigma(\mathrm{C} 2 \mathrm{p}-\mathrm{O} 2 \mathrm{p})-\mathrm{B}$ & $-\mathrm{C}-\mathrm{O}-,-\mathrm{O}-$ \\
\hline & $13.7-9.9$ & $\mathrm{O} 2 \mathrm{p}$ & lonepair-NB & $-\mathrm{O}-$ \\
\hline & & $\mathrm{C} 2 \mathrm{p}$ & $\mathrm{p} \pi(\mathrm{C} 2 \mathrm{p}-\mathrm{C} 2 \mathrm{p})-\mathrm{B}$ & $-\mathrm{C}=\mathrm{C}-$ \\
\hline
\end{tabular}

${ }^{a}$ Shows the peaks range. $W D$ (the gap between observed and calculated VIPs) $=4.0 \mathrm{eV}$.

$\mathrm{H}-(\mathrm{CH}(\mathrm{OOH}) \mathrm{CHR})-\left(\mathrm{CH}_{2} \mathrm{CHR}\right)_{2}-\mathrm{H}\left(\mathrm{R}=\mathrm{H}, \mathrm{CH}_{3}\right), \mathrm{H}-$ $\left.\left(\mathrm{CH}(\mathrm{OOH}) \mathrm{CHC}_{6} \mathrm{H}_{5} \mathrm{CH}_{2} \mathrm{CHC}_{6} \mathrm{H}_{5}\right)-\mathrm{H}\right\}$, and $\{\mathrm{H}-(\mathrm{CH}-$ $\left.\left(\mathrm{OOCH}_{3}\right) \mathrm{CHR}\right)-\left(\mathrm{CH}_{2} \mathrm{CHR}\right)_{2}-\mathrm{H}\left(\mathrm{R}=\mathrm{H}, \mathrm{CH}_{3}\right), \mathrm{H}-(\mathrm{C}-$
$\left.\left.\mathrm{H}\left(\mathrm{OOCH}_{3}\right) \mathrm{C}_{6} \mathrm{H}_{5} \mathrm{CH}_{2} \mathrm{CHC}_{6} \mathrm{H}_{5}\right)-\mathrm{H}\right\}$ in Figures 9 and 10 don't correspond to the experimental ones, since the intense peaks of simulated spectra due to lone-pair 
electrons of oxygen atoms the at around $5 \mathrm{eV}$ didn't reproduce the experimental ones. Those results are also confirmed from the analysis of $\mathrm{C} 1 \mathrm{~s}$ spectra.,

In Table II, we showed the observed peaks, calculated peaks, VIP, main AO photo-ionization crosssection, orbital nature and the functional group for valence XPS of the molecule, $\mathrm{H}-\left(\mathrm{CH}(\mathrm{OH}) \mathrm{CHC}_{6} \mathrm{H}_{5} \mathrm{CH}_{2}\right.$ $\left.\mathrm{CHC}_{6} \mathrm{H}_{5}\right)-\mathrm{H}$ for PS polymer. In c) of Figure 7, the peak located around $30 \mathrm{eV}$ corresponds to ionization from $\mathrm{s} \sigma(\mathrm{C} 2 \mathrm{~s}-\mathrm{O} 2 \mathrm{~s})$ bonding orbital that is related to $\mathrm{C}-\mathrm{O}-$ bond. The next intensive valence peak situated at around $20 \mathrm{eV}$ can be attributed to $\mathrm{s} \sigma(\mathrm{C} 2 \mathrm{~s}-\mathrm{C} 2 \mathrm{~s} ; \mathrm{C} 2 \mathrm{~s}-$ $\mathrm{O} 2 \mathrm{~s}$ ) bonding orbitals due to $(\mathrm{C}-\mathrm{C}=$, phenyl $\mathrm{C}=\mathrm{C})$ and $\mathrm{C}-\mathrm{O}-$ bonds, respectively. The peaks at around 17 and $14 \mathrm{eV}$ are related to $\{\mathrm{s} \sigma(\mathrm{C} 2 \mathrm{~s}-\mathrm{C} 2 \mathrm{~s}), \mathrm{p} \sigma(\mathrm{C} 2 \mathrm{~s}-\mathrm{C} 2 \mathrm{p})\}$ and $\{\mathrm{p} \sigma(\mathrm{C} 2 \mathrm{~s}-\mathrm{C} 2 \mathrm{p}), \mathrm{p} \sigma(\mathrm{C} 2 \mathrm{~s}-\mathrm{O} 2 \mathrm{p})\}$ bonding orbitals, respectively.

\section{CONCLUSIONS}

We analyzed the surface of hydrocarbon polymers (PE, PP, PS) by He-ion bombardment from the theoretical and experimental valence X-Ray photoelectron spectra (XPS). The polymers were He-ion bombarded at an energy of $150 \mathrm{keV}$ with fluences between $1 \times 10^{12}$ and $1 \times 10^{15}$ ions $\mathrm{cm}^{-2}$. We considered that experimental results for valence XPS of the polymers due to the bombardment were simulated by deMon densityfunctional theory (DFT) calculations using the model trimer or dimer of neutral, radical, cationized, and oxidized compounds.

(1) In the He-ion bombardment fluence range of $1 \times$ $10^{12}-1 \times 10^{14}$ ions $\mathrm{cm}^{-2}$, the carbon radical or cation on carbon atoms occurs on the main chain of $\mathrm{PE}, \mathrm{PP}$, and $\mathrm{PS}$ polymers after the $\mathrm{C}-\mathrm{H}$ scission.

(2) In the case of oxidized states (in the He-ion bombardment of $1 \times 10^{15}$ ions $\mathrm{cm}^{-2}$ ), there are the oxidized models aldehyde $\mathrm{H}-\left(\mathrm{CORR}^{\prime} \mathrm{RR}^{\prime} \mathrm{R}\right)_{m^{-}}$ $\mathrm{H}$, or ketone $\left.\mathrm{H}-\left(\mathrm{RR}^{\prime} \mathrm{COR}^{\prime} \mathrm{RR}^{\prime}\right)_{m}-\mathrm{H}\right\}$, and \{alcohol $\mathrm{H}-\left(\mathrm{CH}-(\mathrm{OH}) \mathrm{R}^{\prime} \mathrm{RR}^{\prime} \mathrm{RR}^{\prime}\right)_{m}-\mathrm{H}$, or ether $\left.\mathrm{H}-\left(\mathrm{RC}\left(\mathrm{OCH}_{3}\right) \mathrm{RR}^{\prime} \mathrm{RR}^{\prime}\right)_{m}-\mathrm{H}\right\} \quad\left(\mathrm{R}, \mathrm{R}^{\prime}\right)=\left(\mathrm{CH}_{2}\right.$, $\left.\mathrm{CHX}\left(\mathrm{X}=\mathrm{H}, \mathrm{CH}_{3}, \mathrm{C}_{6} \mathrm{H}_{5}\right)\right)$, respectively on the surface of the polymers.

Acknowledgment. We acknowledge Dr. K. Suzuki of Institute of Physical and Chemical Research (RIKEN) for his experiment using a RIKEN $200 \mathrm{kV}$ Low Current Implanter.

\section{REFERENCES}

1. G. Marletta, C. Oliveri, G. Ferila, and S. Pignataro, Surf. Interface Anal., 12, 447 (1988).

2. M. Iwaki, K. Yabe, A. Fukuda, H. Watanabe, A. Itoh, and M. Takabe, Nucl. Instrum. Methods, B80/81, 1080 (1993).

3. Y. Suzuki, M. Kusakabe, M. Iwaki, K. Kusakabe, H. Akiba, and S. Sato, Mater. Res. Soc. Symp. Proc., 110, 669 (1989).

4. Y. Suzuki, M. Kusakabe, K. Kusakabe, H. Akiba, and M. Iwaki, Nucl. Instrum. Methods, B59/60, 698 (1991).

5. Y. Suzuki, M. Kusakabe, M. Iwaki, H. Akiba, and K. Kusakabe, J. Radiat. Phys. Chem., 39, 533 (1992).

6. Y. Suzuki, M. Kusakabe, J.-S. Lee, M. Kaibara, M. Iwaki, and H. Sasabe, Nucl. Instrum. Methods, B65, 142 (1992).

7. Y. Suzuki, M. Kusakabe, M. Kaibara, M. Iwaki, H. Sasabe, and T. Nisizuka, Nucl. Instrum. Methods, B91, 588 (1994).

8. A. Nakao, M. Kaibara, M. Iwaki, Y. Suzuki, and M. Kusakabe, Appl. Surf. Sci., 100/101, 112 (1996); ibid. Surf. Interf. Anal., 24, 252 (1996).

9. A. Nakao, Y. Suzuki, M. Kaibara, T. Tsukamoto, and M. Iwaki, J. Electron Spectrosc. Relat. Phenom., 88/91, 945 (1998).

10. A. St-Amant and D. R. Salahub, Chem. Phys. Lett., 169, 387 (1990); A. St-Amant, Ph.D. Thesis, University of Montreal (1991).

11. J. C. Slater, Adv. Quantum Chem., 6, 1 (1972).

12. K. Endo, Y. Kaneda, H. Okada, D. P. Chong, and P. Duffy, J. Phys. Chem., 100, 19455 (1996).

13. K. Endo, S. Maeda, and M. Aida, Polym. J., 29, 171 (1997).

14. K. Endo, S. Maeda, and Y. Kaneda, Polym. J., 29, 255 (1997).

15. K. Endo and D. P. Chong, J. Surf. Anal., 3, 618 (1997).

16. S. Kuroki, K. Endo, S. Maeda, D. P. Chong, and P. Duffy, Polym. J., 30, 142 (1998).

17. K. Endo and D. P. Chong, J. Surf. Anal., 4, 50 (1998).

18. T. Otsuka, K. Endo, M. Suhara, and D. P.Chong, J. Mol. Struct., 522, 47 (2000).

19. U. Gelius and K. Siegbahn, Faraday Discus. Chem. Soc., 54, 257 (1972) ; U. Gelius, J. Electron. Spectrosc. Relat. Phenom., 5, 985 (1974).

20. J. F. Janak., Phys. Rev., A18, 7165 (1978).

21. L. Asbrink, C. Fridh, and E. Lindholm, Chem. Phys. Lett., 52, 69 (1977).

22. M. J. S. Dewar and E. G. Zoebisch., THEOCHEM, 180, 1 (1988); M. J. S. Dewar, E. G. Zoebisch., E. F. Healy, and J. J. P. Stewart, J. Am. Chem.Soc., 107, 3902 (1985).

23. A. D. Becke., Phys. Rev., A38, 3098 (1988).

24. J. P. Perdew, Phys. Rev., B33, 8822 (1986).

25. J.-J. Yeh, "Atomic Calculation of Photoionization CrossSections and Asymmetry Parameters", Gordon and Breach Science Publishers, Berkshire, UK, 1993.

26. K. Endo, N. Kobayashi, M. Aida, and T. Hoshi, Polym. J., 28, 901 (1996).

27. K. Endo, T. Hoshi, N. Kobayashi, H. Miura, and M. Kudo, Polym. J., 29, 457 (1997). 